\title{
Conceptualizing power to study social-ecological interactions
}

\author{
Wiebren J. Boonstra ${ }^{1}$
}

\begin{abstract}
My aim is to conceptualize power using social science theory and to demonstrate why and how the concept of power can complement resilience studies and other analyses of social-ecological interaction. Social power as a scientific concept refers to the ability to influence both conduct and context. These two dimensions of power (conduct and context) can be observed by differentiating between various sources of power, including, for example, technology or mental power. The relevance of the conceptualization of power presented here is illustrated with the example of fire as a source of social-ecological power. I conclude by discussing how attention to power can help to address issues of social justice and responsibility in social-ecological interactions.
\end{abstract}

Key Words: fire domestication; power; resilience; social responsibility; social-ecological interactions; sociology

\section{INTRODUCTION}

Social scientists from diverse disciplines have argued that resilience approaches need to account better for how power relations shape social-ecological interactions, and vice versa, if the objective is to understand social dynamics (Nadasdy 2007, Hornborg 2009, 2013, Meadowcroft 2009, Davidson 2010, Smith and Stirling 2010, Brown and Westaway 2011, Pelling and Manuel-Navarrete 2011, Watts 2011, Béné et al. 2012, Cote and Nightingale 2012, Hatt 2013). For example, in this journal, Voß and Bornemann (2011:15, 20, respectively) find that resilience studies are "depoliticized" and disregard "nasty politics", and Smith and Stirling (2010) urge resilience scholars to analyze power explicitly.

In respone to these concerns, my objective in this paper is to review and synthesize social science theory to facilitate a useful engagement between studies of resilience and the concept of power. The article comprises three parts. First, I briefly review the critique, and how resilience scholars so far have dealt with power conceptually and empirically. Second, I review how power has been used as central concept in social scientific theory, and I introduce a conceptualization of power to study social-ecological interactions. Finally, I illustrate how power can be used to study social-ecological interactions based on the example of fire domestication, and I discuss implications for further research.

\section{THE PROBLEM WITH POWER}

A closer look at studies of resilience reveals that several of its core concepts resonate with the idea of power as a (human) capacity to act in social and ecological conditions. Resilience studies focus on social-ecological systems and try to explain their evolution (regime shifts or transformations) and involution (socialecological traps) by analyzing causality from social-ecological interaction. For this purpose, they frequently, but not exclusively, rely on three concepts: resilience, adaptability, and transformability. Resilience is a property of social-ecological systems and refers to the "capacity to absorb disturbance and reorganize while undergoing change so as to still retain essentially the same function, structure, and feedbacks" (Folke et al. 2010:3). Adaptability refers to the capacity to learn and use knowledge to adjust behavior according to changes from within or outside a social-ecological system. Through adaptation, organisms succeed to remain within a regime of alternative social-ecological system conditions (Folke et al. 2010). Transformability also refers to capacity, namely the capacity to produce a change between regimes. It includes "the capacity to transform the stability landscape itself to create a fundamentally new system" (Folke et al. 2010:3).

The choice of the word "capacity" in the above definitions indicates that resilience, adaptability, and transformability resonate with power understood as ability. In line with these definitions, several resilience studies have measured the abilities of persons or groups to influence social-ecological change (Pinkerton 2009, Crona and Bodin 2010, Westley et al. 2013). These and other studies (Peterson 2000, Kofinas 2009, Duit et al. 2010, Olsson et al. 2014) indicate that the engagement with the concept of power can help to uncover various dimensions and sources of resilience, adaptability, and transformability. However, despite these gains, references to the social scientific literature on power in resilience studies remain limited. Resilience scholars acknowledge that they have been "relatively silent" when it comes to addressing the issue of power relations (Berkes and Ross 2013:17), even though, as the foregoing suggests, the concept of power is not incommensurable with resilience concepts. The problem rather seems to be how to engage the concept of power in studies of social-ecological interaction.

The social scientific literature on power is far from straightforward, as I will demonstrate in more detail in the next section (Sources and Dimensions of Power). Moreover, using power as a concept will draw resilience scholars into ontological debates that until now have not explicitly influenced their studies. One such debate revolves around the question of whether power should be considered a property of systems, structures, and events, or a property of distinct actors. Indeed, resilience studies rarely clarify how the central concepts of resilience, adaptability, and transformability can refer to properties of social-ecological systems as well as to the organisms and humans that inhabit them. This distinction is nevertheless important because it is required to allocate responsibility for outcomes (Morriss 2002, Young 2006).

Differentiation between system properties and actor properties is important to "keep alive the crucial question of the moral and the political responsibility of the powerful for what they do and what they fail to do in the past and in the future" (Hayward and 
Lukes 2008:14; see also Schaap 2000). Still, drawing direct causal links between collective outcomes and individual actors is complicated for social-ecological systems. Resilience studies frame social-ecological interactions as dynamic relations between parts and wholes, which redirects focus to how the actions of parts interlink to cause structural outcomes such as regime shifts or traps (Levin et al. 2013, West et al. 2014). Because the socialecological interactions under study take place across global and local scales, it often becomes difficult to clearly demonstrate causal connections, i.e., to trace which specific action of which specific actors caused which specific harm or good. Consequently, it is often problematic to assign responsibility for the evolution and involution of social-ecological interactions. A number of resilience scholars have addressed this problem through the introduction of concepts to capture how distinct individuals, networks, organizations, and institutions (Österblom and Folke 2013) influence the resilience of social-ecological systems, e.g., institutional entrepreneurs (Olsson et al. 2004, Westley et al. 2013) or keystone actors (Österblom et al. 2015). I will return to these questions and efforts in the discussion section. In the following sections, I will first review the debate on power as social science concept and then use this debate to conceptualize power as a tool for the analysis of social-ecological interactions.

\section{SOURCES AND DIMENSIONS OF POWER}

According to a well-known statement, the concept of power should be considered just as fundamental to the social sciences as the concept of energy is to physics (Russell 1938 [1939]:10). Power is deemed fundamental, first because it can explain social causality (Hobbes 1839 [1655]; see also Sayer 2012, Reed 2013). A study of power can highlight how our own and other people's abilities affect outcomes. This purpose is clearly also relevant for resilience studies. As noted previously, the various sources and dimensions of power can help to clarify and measure different aspects of adaptability, transformability, and resilience (Peterson 2000, Kofinas 2009, Pinkerton 2009, Crona and Bodin 2010, Duit et al. 2010, Westley et al. 2013, Olsson et al. 2014). However, this is not the only reason why power is an important concept for social scientists; there are two more reasons for studying power (Morriss 2002). The second reason is to assign responsibility to people for bringing about certain desirable or undesirable outcomes. The third reason is to assess the performance of social systems and institutions, i.e., the extent to which systems and institutions help people in societies to meet their needs and wants, free from the power of others (Hayward and Lukes 2008). These last two reasons refer to purposes that resilience studies might not explicitly consider, but which would nevertheless be relevant: Locating responsibility for the outcomes of social-ecological interactions is crucial for political and legal reasons, and assessing the sustainability performance of social arrangements in relation to social justice and equity is important for moral and ethical reasons.

If these reasons for using power as a concept to study socialecological interactions seem plausible, the next step would be to handle the confetti of labels and theories that come with the term. Indeed, as some famous scholars noticed long ago, power is not a straightforward concept. In 1922, Max Weber concluded that power is "sociologically amorphous" (Weber 1978 [1922]:53), while Talcott Parsons in 1963 noted a "lack of agreement [...] about its specific definition" (Parsons 1963:232). Today, little seems to have changed. Social scientists comment that power is a "perpetually contested concept in social theory" (Wright 2010:111) and an "overburdened term" (Sayer 2012:179). The difficulties of defining what power is and how it can be studied most likely stem from its "polymorphous nature" (Elias 2012 [1970]:88). Power is shapeshifting; it is what its environment makes it, and therefore, it exists in many forms, e.g., economic power, military power, or symbolic power, that can transform into one another (Russell 1938 [1939], Poggi 2001).

As introduced earlier, a conventional way to define power is by referring to abilities or capacities (Morriss 2002). In this understanding, power refers to people's abilities and dispositions to influence outcomes. Power sources such as wealth, muscle power, reputation, social connections, access to natural resources, or technology, are often used to signal these abilities. It is true that the ability of people to exercise power depends on such sources, but it is important to realize that these sources in and of themselves do not constitute power. One of the most influential social science definitions of power explicates that power defined as ability ("power to") necessarily always relates to power over others ("power over"). Accordingly, Max Weber defined power as "the probability that one actor within a social relationship will be in a position to carry out his own will despite resistance, regardless of the basis on which this probability rests" (Weber 1978 [1922]:53). Weber's definition highlights that power only exists through social relationships between persons: it is employed by someone and influences others (see also Elias 2012 [1970], Foucault 1979, 1980). As I explain later, this does not disqualify using sources as indicators of power (see e.g., Giddens 1984, Mann 2002 [1986], Avelino and Rotmans 2011).

Using Weber's definition of power, social scientists shifted focus from sources of power to dimensions of power, i.e., ways in which one person influences the possibilities of another person (Reed 2013). These dimensions of power range from visible activities such as forcing, intimidating, or influencing in direct confrontations (Dahl 1957), to less visible activities such as the shaping of the conditions and terms on which people confront each other (Bachrach and Baratz 1962) and to hidden forms of power such as the shaping of preferences by "influencing people's desires, beliefs and judgments in ways that work against their interests" (Hayward and Lukes 2008:6).

Although highlighting very different dimensions of power, these scholars all refer to the ability of people to shape or influence the conduct of other people. Power in these approaches always has a face, i.e., dimensions of power are always tied to social actors. Inspired by the work of Michel Foucault, social scientists also started to consider forms of power that are "defaced" (Hayward 1998), i.e., ways in which social structures discipline (enable and constrain) human behavior. The crucial insight from these studies is that the power of social actors to influence outcomes (power to) can only exist in conditions that have been socially structured (Pansardi 2012). This means that power does not only refer to the direct dependence between two given people (as in many conventional definitions of power; e.g., Lukes 1974). It also includes the indirect dependence between individual actors and a host of other people that shape the conditions that allow two given people to interact (Elias 2012 [1970]). These conditions include social structures (Merton 1938) and also social events, 
which refer to specific situated actions and interactions in time and place (Reed 2013). Social structures influence human abilities and are shaped by interactions of countless others who are often not immediately visible because they are distant in historical time and geographical space. A social event, on the other hand, refers to the unintended, unanticipated outcome of social interaction, which in turn influences the future actions of persons involved (see Elias 2012 [1970]). The power imbued from social structures or events is of a different kind. Power from social structures refers to how the abilities of actors are shaped by the structures of social relations in which they are embedded, whereas power from social events refers to how time- and place-specific processes of action and interaction enable or limit such abilities (Portes 2000, Reed 2013).

There is considerable debate in the social sciences about whether or not social structures and events can count as forms of power (Digeser 1992, Hayward and Lukes 2008). If they are considered as forms of power, there is a danger that power relations are reified. In this case, an abstract system or sequence of events is thought to bear responsibility for a certain outcome (e.g., "capitalism" or a "turn-of-events"), which complicates the moral purpose of power analyses. However, if social structures and events are not treated as dimensions of power, there is a risk of producing a "conspiracy theory of society," the "mistaken theory that whatever happens in society [...] is the result of direct design by some powerful individuals and groups" (Popper 1962 [1945]:95), although situations exist in which people's abilities are not constrained by the conscious doings of others (see Box 1). Not considering these situations impedes the analytical and evaluative purposes of power analyses.

\section{Box 1: Nobody to shoot}

Theorists of power Hayward and Lukes (2008) introduce a scene from John Steinbeck's book The Grapes of Wrath to highlight the difficulties that ensue when people are confronted with socially structured inequalities as a result of power. The scene illustrates that people can be powerless but not dominated, that people can have power that they never exercise, and that people can exercise power without intention or awareness (see also Parsons 1963, Hayward 1998, Foucault 2000 [1982]). The scene features a farmer, named Muley, and his family. They are facing a tractor driver that is about to bulldoze their shack and plough their land. In response to failing cotton harvests during the Dust Bowl in Oklahoma, USA, banks decided to remove tenants from the land and to rationalize harvesting to obtain a last profit before "the land died." When Muley approaches the tractor and threatens to shoot the driver, the driver responds:

"It's not me. There's nothing I can do. I'll lose my job if I don't do it. And look - suppose you kill me? They'll just hang you, but long before you're hung there'll be another guy on the tractor, and he'll bump the house down. You're not killing the right guy." "That's so," the tenant said. "Who gave you orders? I'll go after him." "You're wrong. He got his orders from the bank. The bank told him, 'Clear those people out or it's your job." "Well, there's a president of the bank. There's a board of directors. I'll fill up the magazine of the rifle and go into the bank." The driver said: "Fellow was telling me the bank gets orders from the East. The orders were: 'Make the land show profit or we'll close you up."”
"But where does it stop?" Steinbeck has his farmer ask the driver of the tractor. "Who can we shoot? I don't aim to starve to death before I kill the man that's starving me." "I don't know," the driver replies. "Maybe there's nobody to shoot" (Steinbeck 1992 [1939]:40-41 cited in Hayward and Lukes 2008:17-18).

This dialog clearly shows a situation in which a person is dominated but not necessarily as a result of the doings of specific powerful individuals. In other words, it is a situation in which there is "nobody to shoot." The driver explains that other drivers will come if he is shot. He also points out that a large network of people is responsible for him running down the farmer's house and plowing his land. For Muley, this explanation is difficult to accept because he really wants to hold someone responsible for his misery. At several other places in the book, Steinbeck also captures how structural dimensions of power (what he calls the "the monster") shape the behavior of individuals, such as the tractor driver:

"The driver could not control it - straight across the country it went, curring through a dozen farms and straight back. A twitch at the controls could swerve the cat', but the driver's hands could not twitch because the monster that built the tractors, the monster that sent the tractors out, has somehow got into the driver's hands, into his brain and muscle, had goggled him and muzzled him goggled his mind, muzzled his speech, goggled his perception, muzzled his protest. [...]. He could not cheer or beat or curse or encourage the extension of his power, and because of this he could not cheer or whip or curse or encourage himself" (Steinbeck 1992 [1939]:38).

These examples from The Grapes of Wrath illustrate that it is often impossible, because of complex causality, to track precisely which (past) actions of people cause current wrongdoings. Both Muley and the tractor driver are powerless, not because they are in someone else's power, but because of the social institutions and networks in which they live. They could perhaps have more power if these institutions and networks were organized differently. Such an observation is an evaluation of a society, or part of a society, and not necessarily a distribution of praise or blame to specific individual people (Morriss 2006:129).

These dilemmas are directly relevant for studies of socialecological interactions, including studies of resilience. To understand and change the causal interaction between earth processes and human societies, it is necessary to include human power as well as to understand how this power is shaped through social and ecological conditions. Box 1 presents an outcome of a social-ecological interaction, the Dust Bowl and the response of American society to this ecological threat, that vividly illustrates the tension that can occur between the analytical or evaluative and the moral purpose of an analysis of power.

As a result of its polymorphous nature, the social science definitions of power run into the thousands (Wrong 2009 [1979]). To avoid a perhaps impossible search for a quintessential definition of power (Connolly 1983), scholars now prefer to use Wittgenstein's idea of "family resemblance" (Wittgenstein 2006 [1953], Haugaard 2012) to advocate a plural view that acknowledges power as a cluster of several related but distinct 
aspects (Allen 1999, Morriss 2002, Dowding 2012, Haugaard 2012). Dimensions and sources of power are thus understood as a cluster of characteristics: a family in which members share some traits but no one trait identifies the family as distinct from others (Pigliucci 2003). The traits are not mutually exclusive, but rather presuppose each other. Introducing power as a family resemblance concept avoids equating power exclusively with one of its dimensions or sources (Reed 2013). However, understanding and applying social science concepts of power to the study of social-ecological interactions continues to be complicated. One important reason is that social scientists frequently fail to indicate how dimensions or sources of power relate to one another (e.g., Haugaard 2003, Gaventa 2007), or they repeatedly prioritize one single dimension or source (e.g., Morriss 2002). This failure encourages the interpretation that one or more sources, or dimensions, are essential for some person or activity to count as powerful, and runs counter to the idea of power as a family resemblance concept. I next attempt to amend for this failure by presenting a conceptualization of power that can be used for the study of social-ecological interactions.

\section{CONCEPTUALIZING POWER}

The conceptualization of power presented here is based on Goertz's (2006) guidelines for concept building in the social sciences. These guidelines are used to ascertain the ontological attributes of power ("what it is") that play a key role in its causal effects ("what it does"). Although the conceptualization of power presented here is strongly influenced by the sociological theories just discussed, it will differ from this tradition in its explicit effort to incorporate social-ecological interactions.

Goertz (2006) proposes to conceptualize social phenomena on three levels. I will explain these levels using the concept of resilience to illustrate their interrelation. The basic level refers to the concept as it is used and known in theory. Goertz remarks that, most often, research tries to explain the affirmation of the basic level concept, without indicating its negation. Indeed, negations of resilience are often not explicitly defined (but see Miller et al. 2010 on vulnerability as a possible negation). The secondary level includes the constitutive attributes of the basiclevel concept. In the case of resilience, this would include adaptability and transformability, which are "essential to maintain resilience" (Folke et al. 2010:1) and which can also be dissected into attributes (Walker et al. 2004). The indicator level includes the operationalization of the secondary-level elements. It refers to the level at which empirical data or information can be gathered. Marshall and Marshall (2007), for example, operationalize social resilience with the following indicators: (1) perception of risk associated with change; (2) perception of the ability to plan, learn, and reorganize; (3) perception of the ability to cope; and (4) level of interest in change.

A crucial purpose for conceptualization is to explicate how elements at the indicator and secondary levels combine to form the basic-level concept. Goertz (2006) identifies two principle structures: essentialist structures, highlighting necessary and sufficient conditions; and family resemblance structures in which conditions share certain features. These two structures are opposites because "[the family resemblance structure] contains no necessary conditions. All one needs is enough resemblance on secondary-level dimensions to be part of the family" (Goertz 2006:7). Much of the debate and confusion in social science about the definition of power comes from not clearly distinguishing these two principles.

At the basic level, social scientists are united in defining power intrinsically as a social relation. This basic concept can be labelled as social power in which the (somewhat redundant) adjective refers to its relational character and thus excludes all instances in which people's abilities are not influenced by interactions with others. The debate and confusion begins at the secondary level with the introduction of agent-centered and structural views of power (see Hayward and Lukes 2008, Raik et al. 2008, Nayak et al. 2016). Several scholars have explicated the relations between these two different forms of power. Indeed, as already mentioned, what people can do (their power to) is always limited and enabled through dependency relations that connect them to social structures and events (Haugaard 2003, Elias 2012 [1970]), while at the same time, social structures and events are produced from people's ability to act (Giddens 1984). It is therefore possible to conclude that agency together with structures and events constitute social power: "Power structures [and events] enable and constrain human agency, just as the exercise of power by agents produces and reproduces power structures [and events]" (Raik et al. 2008:736). Making structures, events, and agency logically equivalent acknowledges the empirical observation that, in social reality, the two forms of power (power to and power over) are intimately interrelated (Pansardi 2012). Based on this argument, it follows that both agent-centered and structural dimensions of power together are necessary for social power to exist. It is wrong to think that one of the two is more important (as in an essentialist structure), and equally wrong to think that either one of them constitutes social power (as in a family resemblance structure).

To avoid the agency-structure dualism (and the associated risks of personification and reification, respectively) it is important to re-emphasize that social power refers to the ability of actors to influence outcomes. Based on the foregoing, this ability consists in directly shaping conduct (individual and that of others) as well as shaping the social and ecological contexts that structure the range of possibilities and abilities of others (Hay 1997). Power as "conduct-shaping" thus refers to direct effects that can be observed and empirically verified. In contrast, power as "contextshaping" is an indirect, latent, and often unintended consequence of human behavior and includes the effects that (re)produce structures and events that "alter the parameters of subsequent action" (Hay 1997:51).

Having identified the basic- and secondary-level items of power and the nature of their relationship, it is now possible to populate the level of indicators, i.e., the items that can be used for operationalization. It is not possible to offer a definite and inclusive list of indicators to operationalize the secondary-level concepts because of power's polymorphism and countless definitions. Nevertheless, the literature nearly always includes some reference to the sources of power that people have at their disposal (e.g., Russell 1938 [1939], Mann 2002 [1986], Morriss 2002, Avelino and Rotmans 2009). The relation between sources as indicators and secondary-level concepts uses the family resemblance structure, which means that it allows for substitutability, or equifinality (Goertz 2006). Substitutability 
relations are noncausal relationships indicating that the presence of any type of power source is sufficient to constitute social power. Applying the principle of substitutability prevents the reduction of social power to the sources that the powerful employ (Elias 2012 [1970]). Sources of power do not cause the exercise of power but rather are attributes of power. Another reason for using substitutability and not causality at the indicator level is to allow for variation in the social and ecological conditions that provide power sources. It allows the identification of various bundles of sources to characterize powerful actors and the ways in which they exercise power.

Having identified all three levels of power, it is now possible to outline a general concept of social power. What counts as social power always depends on both conduct-shaping and contextshaping power, but the constitution of these two dimensions of power depends on the various ways in which sources are available, distributed, and mobilized (Fig. 1). This general model of social power has a structure with necessary and sufficient conditions at the secondary level and substitutability at the indicator or data level (Goertz 2006). Generally, there are two ways in which one could approach this model: from the bottom up or the top down (Tilly 1999). For both ways, one starts to analyze the different types of sources that indicate the presence of power as conduct shaping and context shaping. The top-down analysis highlights how social and ecological structures and events condition the distribution, mobilization, and exercise of power (see also Elias 1970 [2012], Goudsblom 2001, Cox and Chicksand 2007). For the bottom-up analysis, the starting point is how actors use these sources of power. Another possible way to differentiate these two approaches is with reference to a Matryoshka, or nesting, doll; the top-down approach starts from the outside and moves to the inside, whereas the bottom-up approach starts from the inside and moves to the outside (see Jentoft 2007).

\section{POWER IN SOCIAL-ECOLOGICAL INTERACTIONS}

A few further specifications are needed to make this general concept of social power suitable for analysis of social-ecological interactions. First of all, the basic-level concept of social power needs to be broadened beyond its focus on interdependencies between people to include the interdependencies between nature and people (Elias 1970 [2012], Goudsblom 2001). Social scientists conventionally associate the use of power with human or social interaction and not with interactions between humans and their biotic and abiotic environment (Latour 1993, Goudsblom 2001, Stone-Jovicich 2015). The natural environment is typically only analyzed as one source of power that is used in human interaction: "[...] what we call Man's power of nature turns out to be a power exercised by some men over other men with nature as its instrument" (Lewis 2001 [1944]:55; see also Avelino and Rotmans 2011). These tacit assumptions in conventional uses and definitions hinder the application of power for analysis of socialecological interactions. In contrast, if the concept of power is broadened to address social-ecological interdependencies, it can be used as a generally applicable concept in sustainability science.

The work of sociologist Johan Goudsblom exemplifies how power is used as a general concept to analyze patterns of socialecological interaction. In a series of books and articles, Goudsblom demonstrates how, in human history, the acquisition of new sources of energy based on firepower transformed the ways in which people and nature interrelated (Goudsblom 2001, 2015, de Vries and Goudsblom 2002). In his magnum opus Fire and Civilization, Goudsblom (2015) recounts the first, big, human-produced social-ecological regime shift: the domestication of fire. He argues that fire domestication occurred through a transition from nonuse to passive use and, finally, active use of fire. By obtaining fire as new source of power, early humans dramatically changed how they could exercise power over the conduct of other human groups, themselves, and other species, as well as the social and ecological contexts in which they lived (see Box 2).

Fig. 1. Conceptual three-level structure of social power. The different types of power sources outlined by Avelino and Rotmans (2011) are included as suggestions to operationalize power as context and conduct shaping. These resources include the following sources of power: human (e.g., human leverage, personnel, members, voters), mental (e.g., information, concepts, ideas, beliefs), monetary (e.g., funds, cash, financial stock), artifactual (e.g., apparatuses, products, construction, infrastructure, art), and natural (e.g., raw materials, physical space, time, organic life). Alternative sources of power can populate this level, depending on the focus of the research.

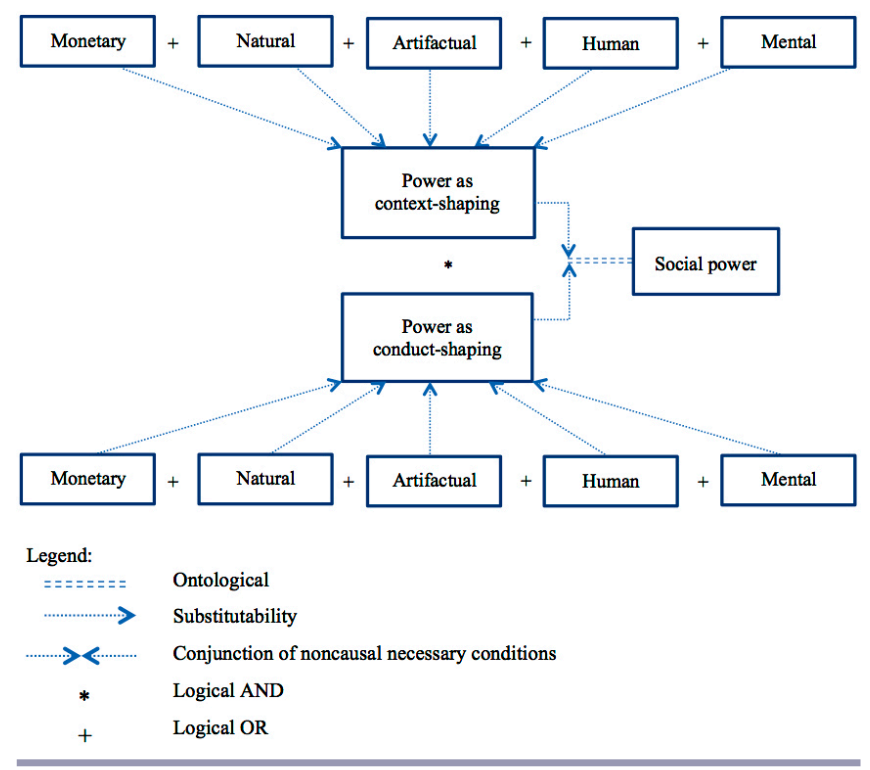

Based on his analysis and other studies, Goudsblom (2001) argues that there seem to be two types of human behavior that are resilient: changes in behavior that generate and consolidate power (see also Giddens 1984), and behavior that adapts to this generation and consolidation of power (see also Scott 1985, 1990, 2009). He even suggests considering changes in balances of power as a central mechanism in the co-evolution of nature and society, complementary to the conventional evolutionary mechanisms of variation, selection, and inheritance (J. Goudsblom, Amsterdam University, 2011 personal communication). The acquisition of new power sources together with accompanying shifts in socialecological interactions stand at the basis of major socialecological transformations and regimes: domestication of fire, domestication of plants and animals, and industrialization (Goudsblom 2015; see also Fisher-Kowalski and Haberl 2007). 


\section{Box 2: Firepower}

Learning how to control fire dramatically changed how humans interconnected with each other and natural environments. It also illustrates how the complex interplay between ecological, social, and psychological dimensions can be analyzed through the concept of power (Table 1). Fire domestication was well established among hominid groups at the earliest in the Middle Pleistocene, 300-500 thousand years ago. Irrespective of the precise start and end points of the domestication of fire, which some claim lie 1.5-2 million years ago (for a debate, see Clark and Harris 1985, Wrangham 2009, Wrangham and Carmody 2010, Sandgathe et al. 2011, Speth 2015), Goudsblom (2015) argues that the mobilization of fire as a source of power occurred in three phases: no hominid groups had fire, some groups had fire, and then finally, all hominid groups had fire.

During the transition from the first to the second phase, some hominid groups must have started to observe and experience wildfires and their effects. In places where fires had occurred, hominids might have found burnt seeds, nuts, fruits, and animals, and experienced the different taste and durability of these items. They also would have experienced the warmth and light of fires. Through observing and experiencing natural fires, hominids seem to have come to appreciate the dangers and benefits of fire. At this first stage, hominids likely passively enjoyed some benefits of fire but without the possibility of actively controling it (Goudsblom 2015). The possibility for more active control of fire developed when hominids were able to walk upright. With their hands free, they had the opportunity to use sticks to poke in fires, keeping themselves at a safe distance, and also to transport fire elsewhere and supply it with fuel. However, as Goudsblom (2015) notes, the physiological capacities of early hominids had to match with social and mental adjustments before passive use could turn into active fire control. In cases where hominids successfully obtained fire from natural burns, they had to ensure it did not extinguish due to rain, moisture, or lack of fuel or oxygen. They had to guard their fires continuously. Importantly, the handling and maintaining of fire required exercise of procrastination, observation, patience, and social negotiation. Evaluating these social and psychological changes, Goudsblom (2015) concludes that the domestication of fire was also a process of selfdomestication (see also Twomey 2013, Pyne 2014). The active use of fire as source of power required changes in human conduct. Before hominids could permanently and actively control fire, the skills and knowledge required for this purpose had to become habitual, i.e., they had to become part of a learned repertoire of shared ways of thinking and doing because they were not part of the hominid genetic composition. With increased selfdomestication, or habituation, hominids' control of fire became more enduring and stable (Roebroeks and Villa 2011).

The use of firepower also irreversibly restructured the ways in which hominids related to their natural environments. It is helpful to make a distinction between on-site and off-site burning (Scherjon et al. 2015). These two types of burning differ in their manifestation and location, but also in their social and environmental effects. The first is contained in a hearth; the second is released in the landscape. The first refers to the use of fire in places where hominids dwelt; the second refers to hominids' use of fire in the wider landscape. On-site burning was used to cook food. Cooking greatly expanded the range of foods that hominids could eat, and it also helped to preserve food items (Wrangham 2009). On-site fire was also used to fend off large animals that preyed on hominids (e.g., saber-toothed cats; Brain 1981), to harden and bend tools, and as a source of warmth and light. The smoke of fires could drive off mosquitos or be used for signaling. In the archeological record, it is notoriously difficult to distinguish natural fires from human-made fires. Nevertheless, based on ethnographic and anthropological research, it is assumed that off-site burning, sometimes called "fire-stick farming" (Jones 1969), helped hominids to improve their access to food and made predators more visible. Scherjon et al. (2015) provide an impressive overview of the reasons for off-site burning, including: clearing vegetation; warfare; driving and attracting animals; signaling; ritual activities; asserting rights to land; clearing pathways, waterholes, and campsites; and aesthetic pleasure and entertainment.

With hominids actively using fire, the world's ecological systems became subjected to more frequent and intense burning (Bowman et al. 2011). Indeed, kindling, quenching, and shuffling fire around constitutes humans' unique "ecological agency" (Pyne 2014:110). This agency is expressed in the growing global abundance of grasslands after fire domestication (Pyne 2012), consisting of mosaic landscapes of fresh grass dotted with forests or groups of trees (Laris 2002, Stewart 2002). Moreover, Goudsblom (2015) argues that the use of fire irreversibly changed the balance of power between hominids and the species they competed with for food (including other hominid groups), or the large carnivores that preyed on humans. The latter two had no choice other than to adapt their behavior to this new source of power. The use of fire radically and irreversibly changed how (early) humans lived in and constructed their social-ecological niche (Odling-Smee et al. 2003).

The ecological, social, and psychological changes involved in the transition from passive to active use of fire reinforced each other. Use of fire improved food security and diet, which contributed to physiological developments, including brain development. Physiological developments were also supported from the social and psychological requirements involved in using fire (Twomey 2013). Fire use had to be learned, which required the exercise of patience, observation, concentration, and communication. The practices of fire use likely produced a (gendered) division of labor whereby some individuals mainly hunted while others guarded fires. These social and psychological changes helped hominids to improve and stabilize their control of fire, and consequently, to shape their social-ecological niche. The changes involved in fire domestication spurred other social developments such as the creation of language, development of tools, population growth, enculturation (learning of socially learned habits, routines, and norms), and social distinction through elaboration of food practices (Harris 1998). During a period of approximately 490,000 years, which some label as the early Anthropocene (Glikson 2013), these changes reinforced each other to the point where some human groups were able to conceive and practice agriculture. 
Table 1. Fire as source of social power to influence social-ecological interactions.

\begin{tabular}{|c|c|c|c|}
\hline \multirow{2}{*}{$\begin{array}{c}\text { Tertiary level: } \\
\text { Sources of social-ecological } \\
\text { power }\end{array}$} & \multicolumn{2}{|c|}{$\begin{array}{c}\text { Secondary level: } \\
\text { Dimensions of social-ecological power }\end{array}$} & \multirow{2}{*}{$\begin{array}{c}\text { Basic level: } \\
\text { Concept of social-ecological } \\
\text { power }\end{array}$} \\
\hline & Fire power as context shaping & Fire power as conduct shaping & \\
\hline $\begin{array}{l}\text { Fire as a natural source of } \\
\text { social and ecological power } \\
\text { used for, among others: } \\
\text { cooking; clearing vegetation; } \\
\text { warfare; driving and } \\
\text { attracting animals; signaling; } \\
\text { ritual activities; asserting } \\
\text { rights; clearing pathways, } \\
\text { waterholes, and campsites; } \\
\text { aesthetic pleasure and } \\
\text { entertainment }\end{array}$ & $\begin{array}{l}\text { The use of fire shaped social and ecological } \\
\text { contexts in the following ways } \\
\text { - Social: active and successful handling of } \\
\text { fire stimulated enculturation (learning of } \\
\text { socially learned habits, routines, and norms); } \\
\text { division of labor } \\
\text { - Ecological: offsite burning created mosaic } \\
\text { landscapes and a permanent shift in the } \\
\text { food web; early humans with control over } \\
\text { fire gained a decisive advantage in } \\
\text { competition for scarce resources with direct } \\
\text { competitors such as other human groups } \\
\text { and large carnivores } \\
\text { - Physiological: cooking changed diets and } \\
\text { improved food security, leading to } \\
\text { physiological changes such as brain } \\
\text { development }\end{array}$ & $\begin{array}{l}\text { The use of fire shaped human and } \\
\text { nonhuman conduct in the following ways } \\
\text { - Human: kindling, guarding, and } \\
\text { transporting fire required collection of fuel } \\
\text { and protection of fire from rain and } \\
\text { moisture; performing these activities } \\
\text { demands procrastination, observation, } \\
\text { patience, and social negotiation; other } \\
\text { human groups that did not control fire had } \\
\text { to adapt their conduct by either acquiring } \\
\text { control over fire as well or avoiding } \\
\text { interactions with human groups using fire } \\
\text { - Nonhuman: other species had to adapt } \\
\text { their behavior to landscape changes due to } \\
\text { more intensive burning; large carnivores had } \\
\text { fewer opportunities to prey on early human } \\
\text { groups who controlled fire }\end{array}$ & $\begin{array}{l}\text { Social power to influence } \\
\text { social-ecological interactions }\end{array}$ \\
\hline
\end{tabular}

\section{CONCLUSION AND DISCUSSION: SOCIAL POWER AND RESPONSIBILITY}

My overall aim here was to investigate how social science theories of power can contribute to research on social-ecological interactions and resilience. This agenda entails finding a concept that can accommodate the practical, moral, and evaluative purposes that are aimed for with an analysis of power in socialecological interaction. Reviewing, synthesizing, and operationalizing social scientific theory on power is not a straightforward task. Power is a polymorphous concept with roots in many different social science traditions. Lately, social scientists have come to consider power as a family resemblance concept to capture its different sources and dimensions. Using these ideas, I conceptualized social power (first level) as comprising two necessary dimensions of conduct shaping and context shaping (second level), which in turn are operationalized as a mixture of power sources (third level). The example of fire as source of socialecological power that shapes both the conduct and context of societies and ecological systems was used to illustrate the workings of this framework (Table 1 and Box 2).

By way of conclusion, I revisit a debate that was introduced earlier and illustrated in Box 1: whether social structures and events can and should be included as dimensions of social power. This debate has direct relevance for approaches that analyze social-ecological interactions with a complex adaptive systems perspective. Studies with this perspective routinely focus on entities that go beyond the individual person or organism, i.e., systems, structures, and networks, and their causal influences on social-ecological interactions. The vulnerability of a complex adaptive systems perspective, or any type of systems thinking, is that it explains inequality, fairness, or unsustainability as systemic properties and mechanisms, e.g., as effects produced from feedback and mismatch between properties in social and ecological systems. Not only can this induce reification, it also complicates allocating responsibility for outcomes of complex processes of social- ecological interaction. Take, for example, the idea of the Anthropocene, for which humanity as a whole is identified as the cause of biosphere change. In a recent article, Baskin (2015:16) argues that this framing tends to dilute questions about responsibility: "By labelling the epoch 'Anthropocene', and the driver - the cause of the massive impacts on the biosphere - as humanity, a particular dynamic is invoked. Impacts which have been driven by (and largely for the benefit of) a minority are attributed to all of humanity. [...]. The Indian subsistence farmer, the African herder and the Peruvian slum-dweller become part of one and the same 'humanity' together with the inhabitants of the rich world, despite clearly having played a different role in ecological devastation and planetary overshoot. In short, the term 'Anthropocene' reveals the power of humans, but it conceals who and what is powerful, and how that power is enacted." The problem with these analyses is that the production of power in complex and functional interdependencies remains obscure (Foucault as cited in Dreyfus and Rabinow 1982:182) and therefore fails to address adequately the responsibility for outcomes in complex social-ecological systems.

Admittedly, it is perhaps an insuperable challenge to tease out who is responsible for what in complex causal chains of socialecological interaction from a conventional account of responsibility. Responsibility is conventionally assigned in terms of blame or fault for an isolated, discrete action or event, in other words, when a fairly clear causal connection between an actor and an outcome can be established. In these cases, actors can be considered liable and be held responsible to compensate for harm done. From a "liability perception of responsibility" (Young 2006), it is often difficult to assign responsibility to specific people in complex social-ecological processes. Indeed, it often proves unfeasible to identify causal relations between individual actions and undesirable collective outcomes, which complicates retribution and compensation on an individual basis. Still, actors that are relatively remote in time and place from the outcome 
under scrutiny are not totally blameless because there is an indirect causal connection between their behavior and social and ecological consequences (Milgram 1974, Lachs 1981).

The concept of social power presented here can help to address the issue of responsibility for outcomes of social-ecological interactions. Using a three-level structure with necessary and sufficient conditions at the secondary level and substitutability at the indicator or data level, the concept sensitizes how people's mobilization of sources of power influences both socialecological conduct and context. It follows that this framework expands to include structures and events as dimensions of power. As such, it complements systems perspectives. However, to use social power for the allocation of responsibility requires a shift from identifying "liability" to acknowledging "social connections" (Young 2006).

As argued, tracing causal relations between actions of particular actors and undesirable outcomes is often impossible in complex social-ecological processes. Consequently, retribution and compensation may not be feasible goals for such a context. However, there still remains a need to deal with responsibility because although the direct influences of distant others on an outcome cannot be traced, those people nevertheless bear responsibility. Their actions contribute to social-ecological interactions that produce harmful or undesirable situations. To assess the degree of responsibility for situations in which a fairly direct relation cannot be established between the actions of a person or group and the harm caused, Young (2006) developed a "social connection perspective" on responsibility. With this perspective, she proposes to focus on the interdependency relations between actors and the extent to which these actors can shape these relations, i.e., their social power. "The social connection [perspective] says that individuals bear responsibility for structural injustice because they contribute by their actions to processes that produce unjust outcomes. Our responsibility derives from belonging together with others in a system of interdependent processes of cooperation and competition through which we seek benefits and aim to realize projects" (Young 2006:119). Young (2006) also argues that with more power to shape these interdependent relations comes more responsibility (see also Lee 1962). The social connection perspective shifts focus on shared responsibility for outcomes from emphasis on blaming or punishing distinct individuals or groups; it aims to prevent people from shunning responsibility but notes that this responsibility is partial because individuals alone cannot produce or change the outcomes from structural and functional interdependence. It follows that changing outcomes requires collective action to take effect (see also power sharing as discussed by Kofinas 2009 and Pinkerton 2009). The social connection perspective diverges from the liability perspective but is not meant to replace or reject the latter. Rather, the two perspectives should be used complementarily, and an important task will be to assess which perspective applies for which situation, i.e., to distinguish between different kinds and degrees of responsibility based on an analysis of social power (see Elias 2012 [1970]). The concept of social power, as developed here, could be used as a tool for this purpose because it includes and integrates dimensions of power related to individual actions (conduct) as well as social-ecological structures and events (context).
Responses to this article can be read online at: http://www.ecologyandsociety.org/issues/responses. $\mathrm{php} / 7966$

\section{Acknowledgments:}

I am grateful to Sofie Joosse, Simon West, and the reviewers and editors of Ecology and Society for helpful comments and suggestions. This paper is a deliverable of the project Green Growth Based on Marine Resources: Ecological and SocioEconomic Constraints (GreenMAR), which is funded by Nordforsk. The research for this paper was further supported by FORMAS Project Grant (2009-631 252) "Regime shifts in the Baltic Sea ecosystem" and FORMAS Project Grant (2013-632 1293) "Working knowledge in Swedish coastal fishery - Making cultural capital visible for sustainable use of coastal sea- and landscapes". Mistra supported the research for this paper through a core grant to the Stockholm Resilience Centre. Research presented here contributes to the Nordic Centre for Research on Marine Ecosystems and Resources under Climate Change (NorMER) funded by Nordforsk.

\section{LITERATURE CITED}

Allen, A. 1999. The power of feminist theory: domination, resistance, solidarity. Westview Press, Boulder, Colorado, USA.

Avelino, F., and J. Rotmans. 2009. Power in transition: an interdisciplinary framework to study power in relation to structural change. European Journal of Social Theory 12 (4):543-569. http://dx.doi.org/10.1177/1368431009349830

Avelino, F., and J. Rotmans. 2011. A dynamic conceptualization of power for sustainability research. Journal of Cleaner Production 19(8):796-804. http://dx.doi.org/10.1016/j.jclepro.2010.11.012

Bachrach, P., and M. S. Baratz. 1962. The two faces of power. American Political Science Review 56(4):947-952. http://dx.doi. org/10.2307/1952796

Baskin, J. 2015. Paradigm dressed as epoch: the ideology of the Anthropocene. Environmental Values 24(1):9-29. http://dx.doi. org/10.3197/096327115x14183182353746

Béné, C., R. G. Wood, A. Newsham, and M. Davies. 2012. Resilience: new utopia or new tyranny? Reflection about the potentials and limits of the concept of resilience in relation to vulnerability reduction programmes. IDS Working Papers 405:1-61. http://dx.doi.org/10.1111/j.2040-0209.2012.00405.x

Berkes, F., and H. Ross. 2013. Community resilience: toward an integrated approach. Society and Natural Resources 26(1):5-20. http://dx.doi.org/10.1080/08941920.2012.736605

Bowman, D. M. J. S., J. Balch, P. Artaxo, W. J. Bond, M. A. Cochrane, C. M. D'Antonio, R. DeFries, F. H. Johnston, J. E. Keeley, M. A. Krawchuk, C. A. Kull, M. Mack, M. A. Moritz, S. Pyne, C. I. Roos, A. C. Scott, N. S. Sodhi, and T. W. Swetnam. 2011. The human dimension of fire regimes on Earth. Journal of Biogeography 38(12):2223-2236. http://dx.doi.org/10.1111/ j.1365-2699.2011.02595.x 
Brain, C. K. 1981. The hunters or the hunted? An introduction to African cave taphonomy. University of Chicago Press, Chicago, Illinois, USA.

Brown, K., and E. Westaway. 2011. Agency, capacity, and resilience to environmental change: lessons from human development, well-being, and disasters. Annual Review of Environment and Resources 36:321-342. http://dx.doi.org/10.1146/ annurev-environ-052610-092905

Clark, J. D., and J. W. K. Harris. 1985. Fire and its roles in early hominid lifeways. African Archaeological Review 3(1):3-27. http:// dx.doi.org/10.1007/bf01117453

Connolly, W. E. 1983. The terms of political discourse. Blackwell, London, UK.

Cote, M., and A. J. Nightingale. 2012. Resilience thinking meets social theory: situating social change in socio-ecological systems (SES) research. Progress in Human Geography 36(4):475-489. http://dx.doi.org/10.1177/0309132511425708

Cox, A., and D. Chicksand. 2007. Are win-wins feasible? Power relationships in agri-food supply chains and markets. Pages 74-99 in D. Burch and G. Lawrence, editors. Supermarkets and agri-food supply chains: transformations in the production and consumption of foods. Edward Elgar, Cheltenham, UK.

Crona, B., and Ö. Bodin. 2010. Power asymmetries in small-scale fisheries: a barrier to governance transformability? Ecology and Society 15(4):32. [online] URL: http://www.ecologyandsociety. org/vol15/iss4/art32/

Dahl, R. A. 1957. The concept of power. Behavioural Science 2 (3):201-215. http://dx.doi.org/10.1002/bs.3830020303

Davidson, D. J. 2010. The applicability of the concept of resilience to social systems: some sources of optimism and nagging doubts. Society and Natural Resources 23(12):1135-1149. http://dx.doi. org/10.1080/08941921003652940

de Vries, B., and J. Goudsblom. 2002. Mappae Mundi: humans and their habitats in a long-term socio-ecological perspective: myths, maps, and models. Amsterdam University Press, Amsterdam, The Netherlands.

Digeser, P. 1992. The fourth face of power. Journal of Politics 54 (4):977-1007. http://dx.doi.org/10.2307/2132105

Dowding, K. 2012. Why should we care about the definition of power? Journal of Political Power 5(1):119-135. http://dx.doi. org/10.1080/2158379X.2012.661917

Dreyfus, H. L., and P. Rabinow. 1982. Michel Foucault: beyond structuralism and hermeneutics. University of Chicago Press, Chicago, Illinois, USA.

Duit, A., V. Galaz, K. Eckerberg, and J. Ebbesson. 2010. Governance, complexity, and resilience. Global Environmental Change 20(3):363-368. http://dx.doi.org/10.1016/j.gloenvcha.2010.04.006

Elias, N. 2012 [1970]. What is sociology? The collected works of Norbert Elias. Volume 5. University College Dublin Press, Dublin, Ireland.

Fischer-Kowalski, M., and H. Haberl, editors. 2007. Socioecological transitions and global change: trajectories of social metabolism and land use. Edward Elgar, Cheltenham, UK. http:// dx.doi.org/10.4337/9781847209436

Folke, C., S. R. Carpenter, B. Walker, M. Scheffer, T. Chapin, and J. Rockström. 2010. Resilience thinking: integrating resilience, adaptability and transformability. Ecology and Society 15(4):20. [online] URL: http://www.ecologyandsociety.org/vol15/iss4/ art20/

Foucault, M. 1979. Discipline and punish: the birth of the prison. Vintage Books, New York, New York, USA.

Foucault, M. 1980. History of sexuality. Volume 1: an introduction. Vintage Books, New York, New York, USA.

Foucault, M. 2000 [1982]. The subject and power. Pages 326-348 in J. D. Faubion, editor. Power: essential works of Foucault 19541984. Volume 3. New Press, New York, New York, USA.

Gaventa, J. 2007. Levels, spaces and forms of power: analysing opportunities for change. Pages 204-254 in F. Berenskoetter and M. J. Williams, editors. Power in world politics. Routledge, Abingdon, UK.

Giddens, A. 1984. The constitution of society: outline of the theory of structuration. University of California Press, Berkeley, California, USA.

Glikson, A. 2013. Fire and human evolution: the deep-time blueprints of the Anthropocene. Anthropocene 3:89-92. http://dx. doi.org/10.1016/j.ancene.2014.02.002

Goertz, G. 2006. Social science concepts: a user's guide. Princeton University Press, Princeton, New Jersey, USA.

Goudsblom, J. 2001. Stof waar honger uit ontstond: over evolutie en sociale processen. Meulenhoff, Amsterdam, The Netherlands.

Goudsblom, J. 2015. Vuur en beschaving. Fifth edition. Van Oorschot, Amsterdam, The Netherlands.

Harris, M. 1998. Good to eat: riddles of food and culture. Waveland Press, Long Grove, Illinois, USA.

Hatt, K. 2013. Social attractors: a proposal to enhance "resilience thinking" about the social. Society and Natural Resources 26 (1):30-43. http://dx.doi.org/10.1080/08941920.2012.695859

Haugaard, M. 2003. Reflections on seven ways of creating power. European Journal of Social Theory 6(1):87-113. http://dx.doi. org/10.1177/1368431003006001562

Haugaard, M. 2012. Rethinking the four dimensions of power: domination and empowerment. Journal of Political Power 5 (1):33-54. http://dx.doi.org/10.1080/2158379X.2012.660810

Hay, C. 2002. Political analysis: a critical introduction. Palgrave, Basingstoke, UK.

Hayward, C. R. 1998. De-facing power. Polity 31(1):1-22.

Hayward, C., and S. Lukes. 2008. Nobody to shoot? Power, structure, and agency: a dialogue. Journal of Political Power 1 (1):5-20. http://dx.doi.org/10.1080/17540290801943364

Hobbes, T. 1839 [1655]. The English works of Thomas Hobbes of Malmesbury. J. Bohn, London, UK. 
Hornborg, A. 2009. Zero-sum world: challenges in conceptualizing environmental load displacement and ecologically unequal exchange in the world-system. International Journal of Comparative Sociology 50(3-4):237-262. http://dx.doi. org/10.1177/0020715209105141

Hornborg, A. 2013. Revelations of resilience: from the ideological disarmament of disaster to the revolutionary implications of $(p)$ anarchy. Resilience 1(2):116-129. http://dx.doi.org/10.1080/2169$\underline{3293.2013 .797661}$

Jentoft, S. 2007. In the power of power: the understated aspect of fisheries and coastal management. Human Organization 66 (4):426-437. http://dx.doi.org/10.17730/humo.66.4.a836621h2k5x46m2

Jones, R. 1969. Fire-stick farming. Australian Natural History 16 (7):224-228.

Kofinas, G. P. 2009. Adaptive co-management in social-ecological governance. Pages 77-102 in F. S. Chapin III, G. P. Kofinas, and C. Folke, editors. Principles of ecosystem stewardship: resiliencebased natural resource management in a changing world. Springer, New York, New York, USA. http://dx.doi.org/10.1007/978-0-387-73033-2_4

Lachs, J. 1981. Responsibility and the individual in modern society. Harvester Press, Brighton, UK.

Laris, P. 2002. Burning the seasonal mosaic: preventative burning strategies in the wooded savanna of southern Mali. Human Ecology 30(2):155-186. http://dx.doi.org/10.1023/A:1015685529180

Latour, B. 1993. We have never been modern. Harvard University Press, Cambridge, Massachusetts, USA.

Lee, S. 1962. Spider-Man! Amazing Fantasy 15. Marvel Comics, New York, New York, USA.

Levin, S., T. Xepapadeas, A.-S. Crépin, J. Norberg, A. de Zeeuw, C. Folke, T. Hughes, K. Arrow, S. Barrett, G. Daily, P. Ehrlich, N. Kautsky, K.-G. Mäler, S. Polasky, M. Troell, J. R. Vincent, and B. Walker. 2013. Social-ecological systems as complex adaptive systems: modeling and policy implications? Environment and Development Economics 18(2):111-132. http://dx.doi.org/10.1017/ $\underline{\mathrm{S} 1355770 \mathrm{X} 12000460}$

Lewis, C. S. 2001 [1944]. The abolition of man. Harper Collins, San Francisco, California, USA.

Lukes, S. 1974. Power: a radical view. Macmillan, London, UK. http://dx.doi.org/10.1007/978-1-349-02248-9

Mann, M. 2002 [1986]. The sources of social power. Volume 1: a history of power from the beginning to $A D$ 1760. Cambridge University Press, Cambridge, UK.

Marshall, N. A., and P. A. Marshall. 2007. Conceptualizing and operationalizing social resilience within commercial fisheries in northern Australia. Ecology and Society 12(1):1. [online] URL: http://www.ecologyandsociety.org/vol12/iss1/art1/

Meadowcroft, J. 2009. What about the politics? Sustainable development, transition management, and long term energy transitions. Policy Sciences 42(4):323-340. http://dx.doi. org/10.1007/s11077-009-9097-z
Merton, R. K. 1938. Social structure and anomie. American Sociological Review 3(5):672-682. http://dx.doi.org/10.2307/2084686

Milgram, S. 1974. Obedience to authority: an experimental view. Tavistock, London, UK.

Miller, F., H. Osbahr, E. Boyd, F. Thomalla, S. Bharwani, G. Ziervogel, B. Walker, J. Birkmann, S. van der Leeuw, J. Rockström, J. Hinkel, T. Downing, C. Folke, and D. Nelson. 2010. Resilience and vulnerability: complementary or conflicting concepts? Ecology and Society 15(3):11. [online] URL: http://www. ecologyandsociety.org/vol15/iss3/art11/

Morriss, P. 2002. Power: a philosophical analysis. Second edition. Manchester University Press, Manchester, UK.

Morriss, P. 2006. Steven Lukes on the concept of power. Political Studies Review 4(2):124-135. http://dx.doi.org/10.1111/ j.1478-9299.2006.000104.X

Nadasdy, P. 2007. Adaptive co-management and the gospel of resilience. Pages 208-227 in D. Armitage, F. Berkes, and N. Doubleday, editors. Adaptive co-management: collaboration, learning, and multi-level governance. University of British Columbia Press, Vancouver, Canada.

Nayak, P. K., D. Armitage, and M. Andrachuk. 2016. Power and politics of social-ecological regime shifts in the Chilika lagoon, India and Tam Giang lagoon, Vietnam. Regional Environmental Change, in press. http://dx.doi.org/10.1007/s10113-015-0775-4

Odling-Smee, F. J., K. N. Laland, and M. W. Feldman. 2003. Niche construction: the neglected process in evolution. Princeton University Press, Princeton, New Jersey, USA. http://dx.doi. org/10.1515/9781400847266

Olsson, P., C. Folke, and F. Berkes. 2004. Adaptive comanagement for building resilience in social-ecological systems. Environmental Management 34(1):75-90. http://dx.doi.org/10.1007/s00267-003-0101-7

Olsson, P., V. Galaz, and W. J. Boonstra. 2014. Sustainability transformations: a resilience perspective. Ecology and Society 19 (4):1. http://dx.doi.org/10.5751/ES-06799-190401

Österblom, H., and C. Folke. 2013. Emergence of global adaptive governance for stewardship of regional marine resources. Ecology and Society 18(2):4. http://dx.doi.org/10.5751/ES-05373-180204

Österblom, H., J.-B. Jouffray, C. Folke, B. Crona, M. Troell, A. Merrie, and J. Rockström. 2015. Transnational corporations as 'keystone actors' in marine ecosystems. PloS One 10(5):e0127533. http://dx.doi.org/10.1371/journal.pone.0127533

Pansardi, P. 2012. Power to and power over: two distinct concepts of power? Journal of Political Power 5(1):73-89. http://dx.doi. org/10.1080/2158379X.2012.658278

Parsons, T. 1963. On the concept of political power. Proceedings of the American Philosophical Society 107(3):232-262.

Pelling, M., and D. Manuel-Navarrete. 2011. From resilience to transformation: the adaptive cycle in two Mexican urban centers. Ecology and Society 16(2):11. [online] URL: http://www. ecologyandsociety.org/vol16/iss2/art11/

Peterson, G. 2000. Political ecology and ecological resilience: an integration of human and ecological dynamics. Ecological 
Economics 35(3):323-336. http://dx.doi.org/10.1016/s0921-8009 (00)00217-2

Pigliucci, M. 2003. Species as family resemblance concepts: the (dis-)solution of the species problem? BioEssays 25(6):596-602. http://dx.doi.org/10.1002/bies.10284

Pinkerton, E. 2009. Coastal marine systems: conserving fish and sustaining community livelihoods with co-management. Pages 241-257 in F. S. Chapin III, G. P. Kofinas, and C. Folke, editors. Principles of ecosystem stewardship: resilience-based natural resource management in a changing world. Springer, New York, New York, USA. http://dx.doi.org/10.1007/978-0-387-73033-2_11

Poggi, G. 2001. Forms of power. University of California Press, Berkeley, California, USA.

Popper, K. R. 1962 [1945]. The open society and its enemies. Volume 2: the high tide of prophecy: Hegel, Marx and the aftermath. Harper Torch Books, New York, New York, USA.

Portes, A. 2000. The hidden abode: sociology as analysis of the unexpected. American Sociological Review 65:1-18.

Pyne, S. J. 2012. Fire: nature and culture. Reaktion Books, London, UK.

Pyne, S. J. 2014. Firepower. Interdisciplinary Studies in Literature and Environment 21(1):109-114. http://dx.doi.org/10.1093/isle/ $\underline{\text { isu016 }}$

Raik, D. B., A. L. Wilson, and D. J. Decker. 2008. Power in natural resources management: an application of theory. Society and Natural Resources 21(8):729-739. http://dx.doi.org/10.1080/089$\underline{41920801905195}$

Reed, I. A. 2013. Power: relational, discursive, and performative dimensions. Sociological Theory 31(3):193-218. http://dx.doi. org/10.1177/0735275113501792

Roebroeks, W., and P. Villa. 2011. On the earliest evidence for habitual use of fire in Europe. Proceedings of the National Academy of Sciences 108(13):5209-5214. http://dx.doi.org/10.1073/ pnas. 1018116108

Russell, B. 1938 [1939]. Power: a new social analysis. Allen and Unwin, London, UK.

Sandgathe, D. M., H. L. Dibble, P. Goldberg, S. P. McPherron, A. Turq, L. Niven, and J. Hodgkins. 2011. Timing of the appearance of habitual fire use. Proceedings of the National Academy of Sciences 108(29):E298. http://dx.doi.org/10.1073/ pnas. 1106759108

Sayer, A. 2012. Power, causality and normativity: a critical realist critique of Foucault. Journal of Political Power 5(2):179-194. http://dx.doi.org/10.1080/2158379x.2012.698898

Schaap, A. 2000. Power and responsibility: Should we spare the king's head? Politics 20(3):129-135. http://dx.doi. org/10.1111/1467-9256.00122

Scherjon, F., C. Bakels, K. MacDonald, and W. Roebroeks. 2015. Burning the land: an ethnographic study of off-site fire use by current and historically documented foragers and implications for the interpretation of past fire practices in the landscape. Current Anthropology 56(3):299-326. http://dx.doi.org/10.1086/681561
Scott, J. C. 1985. Weapons of the weak: everyday forms of peasant resistance. Yale University Press, New Haven, Connecticut, USA.

Scott, J. C. 1990. Domination and the arts of resistance: hidden transcripts. Yale University Press, New Haven, Connecticut, USA.

Scott, J. C. 2009. The art of not being governed: an anarchist history of upland Southeast Asia. Yale University Press, New Haven, Connecticut, USA.

Smith, A., and A. Stirling. 2010. The politics of social-ecological resilience and sustainable socio-technical transitions. Ecology and Society 15(1):11. [online] URL: http://www.ecologyandsociety. org/vol15/iss1/art11/

Speth, J. D. 2015. When did humans learn to boil? PaleoAnthropology 2015:54-67. online URL: http://paleoanthro. org/media/journal/content/PA20150054.pdf

Steinbeck, J. 1992 [1939]. The grapes of wrath. Penguin, New York, New York, USA.

Stewart, O. C. 2002. Forgotten fires: Native Americans and the transient wilderness. University of Oklahoma Press, Norman, Oklahoma, USA.

Stone-Jovicich, S. 2015. Probing the interfaces between the social sciences and social-ecological resilience: insights from integrative and hybrid perspectives in the social sciences. Ecology and Society 20(2):25. http://dx.doi.org/10.5751/ES-07347-200225

Tilly, C. 1999. Power-top down and bottom up. Journal of Political Philosophy 7(3):330-352. http://dx.doi.org/10.1111/146$\underline{7-9760.00080}$

Twomey, T. 2013. The cognitive implications of controlled fire use by early humans. Cambridge Archaeological Journal 23 (1):113-128. http://dx.doi.org/10.1017/s0959774313000085

Voß, J.-P., and B. Bornemann. 2011. The politics of reflexive governance: challenges for designing adaptive management and transition management. Ecology and Society 16(2):9. [online] URL: http://www.ecologyandsociety.org/vol16/iss2/art9/

Walker, B., C. S. Holling, S. R. Carpenter, and A. Kinzig. 2004. Resilience, adaptability and transformability in social-ecological systems. Ecology and Society 9(2):5. [online] URL: http://www. ecologyandsociety.org/vol9/iss2/art5

Watts, M. 2011. On confluences and divergences. Dialogues in Human Geography 1(1):84-89. http://dx.doi.org/10.1177/204382$\underline{0610386340}$

Weber, M. 1978 [1922]. Economy and society: an outline of interpretive sociology. University of California Press, Berkeley, California, USA.

West, S., J. Haider, H. Sinare, and T. Karpouzoglou. 2014. Beyond divides: prospects for synergy between resilience and pathways approaches to sustainability. STEPS Working Paper 65. STEPS Centre, University of Sussex, Brighton, UK. [online] URL: http:// steps-centre.org/wp-content/uploads/Resilience-and-Pathways.pdf

Westley, F. R., O. Tjornbo, L. Schultz, P. Olsson, C. Folke, B. Crona, and Ö. Bodin. 2013. A theory of transformative agency in linked social-ecological systems. Ecology and Society 18(3):27. http://dx.doi.org/10.5751/es-05072-180327 
Wittgenstein, L. 2006 [1953]. Filosofische onderzoekingen. Serie grote klassieken. Boom Uitgeverij, Amsterdam, The Netherlands.

Wrangham, R. 2009. Catching fire: how cooking made us human. Basic Books, New York, New York, USA.

Wrangham, R., and R. Carmody. 2010. Human adaptation to the control of fire. Evolutionary Anthropology 19(5):187-199. http:// dx.doi.org/10.1002/evan.20275

Wright, E. O. 2010. Envisioning real utopias. Verso, London, UK.

Wrong, D. H. 2009 [1979]. Power: its forms, bases, and uses. Transaction Publishers, New Brunswick, New Jersey, USA.

Young, I. M. 2006. Responsibility and global justice: a social connection model. Social Philosophy and Policy 23(1):102-130. http://dx.doi.org/10.1017/S0265052506060043 